\title{
Música e desenvolvimento em Salvador (Bahia), à luz da geografia crítica e ecologia dos saberes
}

\author{
Armando Alexandre Castro (UFRB, Santo Amaro, BA) \\ aaccastro@gmail.com
}

Maria Teresa Franco Ribeiro (UFBA, Salvador, BA)

mariatfr@uol.com.br

\begin{abstract}
Resumo: Registro do mapeamento de um conjunto considerável de instituições que utilizam a música como elemento estético-pedagógico relevante na transformação social de cidadãos em Salvador (Bahia), uma cidade que, distante dos discursos turísticos, apresenta consideráveis índices de pobreza, concentração de renda e desigualdade socioeconômica. O referencial teórico está alicerçado na geografia crítica e no conceito de ecologia dos saberes. A metodologia escolhida contempla a coleta e análise de estatísticas socioeconômicas oficiais sobre Salvador, e uma a pesquisa de campo com aplicação de entrevistas semiestruturadas.

Palavras-chave: música e desenvolvimento social; educação musical; geografia crítica; ecologia dos saberes em música.
\end{abstract}

\section{Music and development in Salvador (Brazil), by the light of critical geography and ecology of knowledge}

\begin{abstract}
Mapping of significant institutions using music as an important aesthetic and pedagogical element in the social transformation of citizens in Salvador (Brazil), a city that, far from tourist appeal, presents considerable poverty rates, concentration of income and socioeconomic inequality. The theoretical framework is grounded in critical geography and the concept of ecology of knowledge. The chosen methodology includes the collection and analysis of Salvador's official socioeconomic statistics, and a field research with application of semi-structured interviews.
\end{abstract}

Keywords: music and social development; music education; critical geography; ecology of knowledges.

\section{1 - Introdução}

A partir de uma análise fundamentada, racional e pertinente, pode-se afirmar que os resultados do processo de globalização e os impasses que surgem no plano econômico, social, político e ambiental colocam em xeque os pressupostos e instrumentos de suporte à gestão social e à intervenção sobre a realidade. $\mathrm{O}$ desenvolvimento e o progresso prometidos pela ciência moderna mostraram-se excludentes e perversos, quando se consideram os desafios postos aos países nãodesenvolvidos de competirem nos mercados globais e, simultaneamente, elevarem a qualidade de vida e de bem-estar de suas populações. A manutenção da lógica competitiva dos mercados globais tende a acirrar contradições, exclusão social e desastres ambientais. $\mathrm{O}$ momento atual aponta para a necessidade de renegociação das bases de uma outra sociedade (LEFF, 2006; DUPAS, 2004; SACHS, 2005; 2007). 
Esse processo, segundo DUPAS (2009), acentuou, nas últimas décadas, duas tensões fundamentais que convergem agora para o mesmo impasse estrutural. De um lado, a estagnação dos níveis de pobreza e agravamento da concentração de renda. De outro, o acirramento das questões ambientais provocadas pelo próprio modelo econômico "sucateador" de produtos e "esbanjador" de energia.

No contexto da crise recente do capitalismo, de caráter geral e sistêmico, segundo PAULA (2010), o Brasil mostrou que sua economia é capaz de crescer, mas é estruturalmente incapaz de superar o subdesenvolvimento, na medida em que isso significa transformações estruturais, que passam por uma radical distribuição da renda e da riqueza, da sustentabilidade ambiental, da valorização da diversidade cultural e da eliminação de todas as formas de opressão, objetivos que colidem, consideravelmente, com o modelo capitalista. Isso significa que as discussões aqui desenvolvidas caminham na contramão da ordem capitalista hegemônica, portanto, subordinada a esta. Entretanto, compreendendo o processo histórico como dialético e não linear, acreditamos na importância da compreensão da dinâmica dos movimentos sociais e de organização da sociedade civil como espaços de formação de consciência política fundamental para um projeto emancipatório.

Assim, o final do século XX e início deste são marcados pelo retorno ao debate sobre o desenvolvimento e questões espaciais e ambientais. Percebe-se que, ao longo da expansão e produção do capital, há, simultaneamente, a produção e reprodução de espaços capitalistas. Esse processo aprofunda as desigualdades regionais, sociais e econômicas.

Das diversas abordagens contemporâneas que discutem as bases dessa crise e as possibilidades de superação, grosso modo, ressaltamos quatro contribuições, desde já advertindo para os limites das classificações ou tipologias que abordam temas tão complexos e transversais.

Apenas para exemplificar algumas das diferentes orientações do debate, destacamos quatro abordagens: a primeira interpretação da crise do desenvolvimento emana daqueles que a associam ao modo capitalista de produção e à sua lógica de acumulação. Portanto, sua superação passa, necessariamente, pela própria superação desse modo de produzir, distribuir e se apropriar tanto dos resultados da produção quanto do próprio espaço social. Segundo HARVEY (2005), as dimensões geográficas relativas à acumulação do capital e à luta de classes desempenham um papel fundamental na perpetuação do poder burguês e na supressão dos direitos e aspirações do trabalhador, não apenas em lugares específicos, mas também globalmente.

Uma segunda abordagem, a crítica antropológica, revela o papel do etnocentrismo e do eurocentrismo na definição dos valores e normas do desenvolvimento, enquanto promessa ocidental, ressaltando a natureza histórica e pretensamente universalizante da modernidade. Para essa corrente, os princípios do progresso e da civilização impuseram lógicas e racionalidades como medidas universais para diferentes realidades socioculturais e contextos históricos, e apontam para a 
necessidade de diálogo com/e entre os povos indígenas, assim como sinalizam acerca do respeito às diferentes racionalidades (TUCKER, 1999; SAID, 2007).

A terceira visão, numa mesma linhagem da crítica pós-moderna, adverte para a impossibilidade do caráter universal do desenvolvimento, fruto de uma utopia iluminista que acabou favorecendo os interesses das classes dominantes. Existe, atualmente, um movimento ascendente na Europa, vinculado à escola pósdesenvolvimentista, segundo a qual, assim como o progresso, o desenvolvimento pode trazer consequências sobre a vida e a liberdade dos homens, camuflando os interesses de diversos grupos de poder que se beneficiam desse mesmo processo. Defendem o pós-desenvolvimento e a pesquisa sobre modos de épanouissement coletivos que não buscam apenas o bem-estar material, responsável pela desestruturação do ambiente e das relações sociais, mas respeitam as especificidades dos povos. Ressaltam, assim, a natureza essencialmente plural do desenvolvimento, aquela que se desenha de forma sensivelmente diferente no Norte e no Sul (LATOUCHE, 2004; ESCOBAR, 2007; RIST, 1996).

Finalmente, a quarta abordagem diz respeito à corrente crítica contra-hegemônica que assume os desafios da construção dos valores universais em novas bases. A falta de respostas às questões relacionadas com as desigualdades sociais e a continuidade do tratamento das questões do desenvolvimento, fundamentalmente, na perspectiva econômica, deverão ser a tônica das reivindicações dos movimentos alternativos expressos, principalmente, no âmbito do Fórum Social Mundial. Os trabalhos oriundos desse debate sinalizam a natureza polissêmica e multidimensional do desenvolvimento. Essa corrente recoloca o debate sobre qual globalização se quer construir e os caminhos possíveis (ESCOBAR, 2007; SOUSA SANTOS, 2001; SANTOS, 2001).

Muitos pontos explorados por essas abordagens se entrecruzam, como a questão ambiental e a retomada do debate sobre as dimensões e especificidades dos territórios e seus sujeitos. Todas as abordagens têm uma compreensão e um viés sobre como os problemas desse padrão de desenvolvimento afetam a humanidade, assim como das possibilidades de construção de novos caminhos alternativos. Para SOUSA SANTOS (2007), é necessário muito mais que uma resistência política, mas uma resistência epistemológica, a construção de um pensamento alternativo às alternativas. Importa, para o autor, alterar o domínio do centro e propor alternativas de análise que permitam atuar em duas direções: uma, no sentido de combater a noção dominante de desenvolvimento, concebida a partir de perspectivas hegemônicas do centro; e outra direção, que busca compreender, a partir das bases, como os grupos sociais dialogam com as imposições que the são colocadas e as formas de resistências que têm mobilizado contra estes (MENESES, 2004).

Apesar desse intenso debate, duas "verdades ou mitos" ainda parecem persistir: a primeira, a ideia do desenvolvimento como um caminho linear a ser perseguido, a partir de experiências dos países desenvolvidos ou do Norte; e a segunda, a crença de que a aplicação dos conhecimentos disponíveis podem ser transferidos e aplicados de maneira universal. Esses dois princípios partem do pressuposto de que 
tanto a ideia de desenvolvimento como a de ciência seriam neutras, e que o avanço desta traria, necessariamente, o progresso para todos.

A "crença" na neutralidade da ciência e na "universalidade" dos indicadores de desenvolvimento continua a orientar a elaboração de políticas de desenvolvimento, tanto no Norte, como no Sul. Desconsidera-se a existência de valores sociais e interesses econômicos implícitos na produção do conhecimento científico e tecnológico, bem como as consequências de sua aplicação em contextos históricoculturais específicos. Deixa-se de lado, entretanto, a contribuição dos estudos sociais da ciência na definição de estratégias de desenvolvimento (LATOUR, 2004). Permeia essa visão a concepção de que a produção científica do conhecimento leva sempre à eficiência, e nega a importância de outras formas de conhecimento e saberes construídos ao longo da história, por diferentes sociedades (RIBEIRO, 2009).

Isso não significa desacreditar na ciência ou reduzir a importância do conhecimento científico, mas incentivar o seu uso, também, a partir das necessidades e problemas específicos de cada realidade sociocultural. Um país não pode negligenciar as áreas duras da ciência, como a matemática, engenharias, etc. (SALES, 2010). A compreensão das especificidades culturais e humanas, entretanto, estimularia o diálogo entre a ciência, as artes e as humanidades, dando maior amplitude à sua aplicação. A busca da "completude" do saber e do ser potencializaria uma maior harmonia e respeito entre as diversidades socioespaciais. Esse é o papel estratégico do Estado e das políticas públicas, e é dentro dessa mesma perspectiva que focamos, nesse trabalho, campos sociais em que percebemos a potencialização da criatividade e da cidadania, principalmente, à margem da ação governamental. Esse foco poderia ser estendido para várias outras áreas da ciência, das artes e das humanidades.

A partir de reflexões críticas acerca desses "mitos universais", alguns estudiosos avançam na construção de novos princípios e conceitos que discutem e desconstroem antigas verdades científicas, baseadas no modelo cartesianonewtoniano, e buscam dar conta da intrínseca interconectividade das relações da sociedade com a natureza e da complexidade dos processos de desenvolvimento (CAMARGO, 2005; HISSA, 2002; NICOLESCU, 2001; MORIN, 1999; MORIN e MOIGNE, 2000; SOUSA SANTOS, 2001, 2003). Esses autores realizam um esforço de crítica epistemológica e perseveram na construção de novas bases do conhecimento, valorizando o diálogo entre as suas áreas, e buscando integrar o que foi fragmentado. Assim, tornam complexo o que foi simplificado pela ciência moderna.

Como apontam MORIN e MOIGNE (2000), o sujeito do conhecimento deve ser reavaliado em favor de outras concepções mais interativas, menos antropocêntricas e mais dialógicas, valorizando a arte do pensar. Nessa perspectiva, o conhecimento do homem e suas múltiplas dimensões não pode ser separado do Universo, mas inserido nele. Em outras palavras: "Quem somos é inseparável de onde estamos, de onde viemos e para onde vamos" (MORIN; MOIGNE, 2000, p.36). A compreensão e atuação sobre o local e o território não se limitam ao espaço físico, limitado 
geograficamente, mas, a um espaço possuidor de uma história, de uma cultura e inúmeras oralidades. A compreensão dessa trajetória é fundamental para a construção de uma consciência humanística e ética de pertencer à espécie humana, à dimensão terrestre e à dimensão local, para um agir responsável sobre essa mesma realidade. O agir transformador implica pertencimento, sensibilização e compreensão do processo histórico.

A noção de pertencimento implica um auto-reconhecimento de pessoas capazes de interagir com os outros, de ouvirem e de serem ouvidas, de respeitarem e serem respeitadas Nesse sentido, como ressalta SEGURA (2001), a ampliação das relações de pertencimento depende da predisposição individual e coletiva para mudar o olhar e as atitudes. Esse novo olhar possibilitará a construção dessa nova epistemologia, menos arrogante e mais comprometida com os destinos da Terra. É nessa perspectiva que SOUSA SANTOS (1987) afirma que, na medida em que se superam as dicotomias entre mente e matéria, observador e observado, subjetivo e objetivo, coletivo e individual, animal e pessoas, a distinção entre ciência natural e ciência social deixa de ter sentido.

Neste trabalho, procuramos compreender o crescimento de movimentos culturais, principalmente associados à música, investigando sua natureza alternativa, de resistência à marginalidade que lhes são impostas, a partir da abertura de novas perspectivas de envolvimento e reconhecimento de populações marginalizadas como sujeitos políticos, de valorização e contato com suas raízes históricas e culturais.

\section{2 - Desenvolvimentos e Territórios de Utopias}

A abordagem da geografia crítica percebe a crise como resultante do próprio modelo de expansão capitalista, estando, portanto, sua superação associada à reconfiguração desse modo de produzir, distribuir e se apropriar, tanto dos resultados da produção, quanto do próprio espaço social. Nos últimos anos, experiências de participação democrática, como o orçamento participativo e a criação de fóruns de participação popular têm buscado superar o grande desequilíbrio entre classes e grupos sociais, mas os resultados não são tão animadores no âmbito geral.

Em termos globais, o que se percebe é um aumento da parcela direcionada ao capital e uma redução da parcela apropriada sobre a forma de salário (HARVEY, 2010). Esses resultados são fruto da própria contradição do modo capitalista de produzir, que gera, inevitavelmente, concentração da renda e crises de realização ou superprodução. Essas crises podem ser postergadas pelo ajuste espaço-temporal do excedente econômico, seja pelo deslocamento no tempo dos investimentos de capital em projetos de longo prazo, seja através da incorporação de novos espaços geográficos, incorporação de novos mercados (HARVEY, 2006). É evidente que com a expansão capitalista, o processo de globalização, as possibilidades de realização e eficiência desses ajustes vão ficando cada vez mais longínquos. 
Sem desconsiderar a natureza da crise e suas profundas raízes estruturais, HARVEY (2010) apresenta diversos fatores associados à dinâmica capitalista, apontando, ainda, a criatividade do sistema de encontrar novos caminhos, a partir de novas organizações sociais e tecnológicas. A centralidade da crise no excessivo poder do capital aponta, segundo este autor, para novas oportunidades e transformações desse modo de desenvolvimento rentista, fortemente competitivo e individualista. Não obstante, sinaliza acerca da relevância de se pensar a perspectiva do desenvolvimento humano neste processo, assim como das capacidades humanas de buscar o novo. Neste sentido, a gravidade das condições sociais e ambientais sinaliza a necessidade de se pensar alternativas.

Valorizar aspectos da vida, da sociabilidade e criatividade, como a poesia, a música e as várias áreas das artes e humanidades. A busca pelo inusitado, pela realização e satisfação pessoal seriam os motores da dinâmica do desenvolvimento, e de outras possibilidades de existência menos utilitarista. Não se eliminariam os conflitos e os diversos problemas oriundos dos processos socioespaciais, mas a busca precisa priorizar o "florescimento" da capacidade humana. Como esse processo dialogará com a dinâmica social, política e econômica, somente o decurso da história para mostrar, mas a esperança é que essas atividades ampliem a compreensão do mundo e a ação política.

Nesse sentido, acreditamos que o pensamento de HARVEY (2010) se aproxima das utopias sinalizadas por SANTOS (2000), quando aponta a importância de se pensar o espaço como reprodução da vida, e não apenas da mercadoria. Segundo SMITH (1996), para SANTOS, o espaço era um projeto político, o projeto humanista final: o veículo de libertação que precisa ser refeito não como meio de exploração, mas de reprodução da vida social, como possibilidade de outra globalização, respaldada nas mesmas bases técnicas, mas a serviço de outros objetivos, outros fundamentos sociais e políticos. O autor levanta uma questão importante nesse debate, em que o processo de mundialização do produto, do dinheiro, do crédito, da dívida, do consumo e da informação é, sobretudo, uma tendência, pois (...) "em nenhum país, houve completa internacionalização. O que há em toda parte é uma vocação às mais diversas combinações de vetores e formas de globalização" (SANTOS, 2000, p.30).

Os esforços de SOUSA SANTOS (2007) se dão na mesma direção, se dedicando à compreensão dos motivos pelos quais as promessas emancipatórias da modernidade não se realizaram. O autor esforça-se na construção de novas bases epistemológicas que combatam o pensamento hegemônico ou pensamento ocidental, desde suas formulações, centrando seu discurso naqueles marcos que denominou de Sociologia das Ausências e Ecologia dos Saberes (SOUSA SANTOS, 2007). Assim como SANTOS (2000), SOUSA SANTOS (2009) acredita que o "cosmopolitismo subalterno" contém uma promessa real, apesar de se apresentar ainda bastante embrionário, e, para captar esse movimento, propõe o conceito de "sociologia das emergências", segundo o qual,

[...] consiste numa ampliação simbólica de sinais, pistas e tendências latentes que, embora dispersas, embrionárias e fragmentadas, apontam para novas 
constelações de sentido tanto no que respeita à compreensão, como à transformação do mundo (SOUSA SANTOS, 2009, p.92).

Nessa linha, SANTOS afirma que "[...] Nunca pensamos o mundo a partir da América Latina. [...] Pensamos Europa, Estados Unidos e excluímos a África e a Ásia. [...] Essa é a realidade que cobra de nós (uma) outra epistemologia" (1999, p.37).

Assim, ainda segundo SOUSA SANTOS (2009, p.78), "as linhas cartográficas abissais" que demarcaram o Velho e o Novo Mundo na era colonial subsistem estruturalmente no pensamento moderno ocidental e permanecem constitutivas das relações políticas e culturais excludentes mantidas no sistema mundial contemporâneo. Para o autor, o pensamento moderno é um pensamento abissal formado por distinções visíveis e invisíveis, sendo que estas suportam e fundamentam as expressões visíveis. O pensamento abissal não comporta os dois lados da linha, ele não reconhece o outro lado da linha. O pensamento moderno, ocidental é fundamentado na tensão entre regulação e emancipação social.

O pilar da regulação social é constituído pelo princípio do Estado, princípio da comunidade e do mercado, enquanto o pilar da emancipação consiste nas três lógicas da racionalidade: a racionalidade estética e expressiva das artes e literatura, a racionalidade instrumental cognitiva da ciência e tecnologia, e da racionalidade moral/política da ética e do direito (SOUSA SANTOS, 2009). Ainda há, segundo o autor, subjacente a essa distinção, outra, invisível, na qual a anterior se funda, que é a distinção entre as sociedades metropolitanas e os territórios coloniais. Mas, não raro, a dicotomia regulação/emancipação só se aplica às sociedades metropolitanas. Nos territórios coloniais se aplica outra dicotomia, a dicotomia apropriação/violência. O pensamento ocidental não apenas reforça essa diferença, como a radicaliza. A visibilidade da ciência moderna se assenta na invisibilidade de outras formas de conhecimentos presentes nos territórios coloniais. A negação produz uma ausência: a ausência de humanidade, ou a subumanidade moderna.

A pressão da lógica apropriação/violência sobre a lógica regulação/emancipação gera, aponta este autor, três tipos de fascismo social: o apartheid social (segregação social dos excluídos), o fascismo contratural (privatização dos serviços públicos, saúde, segurança e eletricidade), e o fascismo territorial (apropriação dos territórios, cooptando e violentando as instituições, ou novos territórios coloniais privados. Essas três formas de fascismo ficam muito evidentes ao analisarmos alguns dados socioeconômicos da cidade de Salvador, espaço que discutimos a emergência de alguns movimentos potencializadores de mudança, a partir da arte, especialmente a música. Para captar esses movimentos, SOUSA SANTOS $(2009 ; 2007)$ propõe uma nova epistemologia, mas não de forma excessivamente generalista e ampla, pois hoje, dada a complexidade e pluralidade do mundo, não seria mais possível uma teoria geral.

É na perspectiva da construção dessa nova epistemologia que SOUSA SANTOS (2009; 2007) propõe os conceitos de Sociologia das Ausências e Ecologia dos Saberes. Esse pensamento novo, pós-abissal, uma vez que o pensamento ocidental 
moderno dividiu, reduziu e excluiu experiências e saberes não hegemônicos, expressaria as formas de expressão e vida das comunidades excluídas, invisíveis e silenciosas. Esse novo pensamento eliminaria o desperdício das experiências, e confrontaria a monocultura da ciência moderna com uma ecologia dos saberes.

Trata-se de uma ecologia porque se baseia no reconhecimento da pluralidade de conhecimentos heterogêneos, e em interações sustentáveis e dinâmicas entre eles, sem comprometer sua autonomia (SOUSA SANTOS, 2009). A ecologia dos saberes reconhece a pluralidade de formas de conhecimentos, além daquele produzido pelo mundo científico.

A sociologia das ausências é um conhecimento insurgente, que procura mostrar que o que não existe é produzido como não existente, como alternativa descartável e invisível à realidade hegemônica do mundo. As ausências são produzidas pela monocultura dos saberes, do tempo linear e da naturalização das diferenças, e, ainda pela monocultura da escala dominante (universalismo e globalização). Nessa perspectiva, os países do norte estão na frente, conhecem as aplicações do pensamento científico e devem ser seguidos. Compreender as ausências, suas lógicas e tensões permitem a reinvenção do espaço e 0 acolhimento das diversidades, abrindo possibilidades de transformação das monoculturas dos saberes em ecologias dos saberes.

Esses espaços que HARVEY (2010) aponta para o desenvolvimento humano, das potencialidades das expressões humanas, e que SANTOS (2001) aponta como espaços da utopia. Esses espaços contemplam o diálogo entre ciência e outras formas de saber. Não se constrói novos caminhos de desenvolvimento negando os conhecimentos científicos e tecnológicos, mas construindo ou transformado-os a partir do olhar crítico das necessidades humanas.

\section{3 - O espaço como corpo que abriga as diversidades}

Sob a influência do conjunto das ciências sociais, o território passa da situação de uma descrição de uma malha espacial (no sentido jurídico-administrativo) para o estatuto de conceito que busca dar conta da complexidade da realidade e das construções socioeconômicas inseridas em um espaço físico. O conceito de território remete tanto aos aspectos formais (distribuição no espaço de materiais naturais e construídos, divisões administrativas, políticas e jurídicas), bem como os aspectos ligados ao sentido dessas formas (as ideologias espaciais, representações e sistemas de valores), como menciona BENKO (2007).

O poder do laço territorial revela que o espaço está investido de valores não apenas materiais, mas também éticos, espirituais, simbólicos e afetivos. Nesse sentido, o território cultural precede o território político e precede o espaço econômico (HAESBAERT, 2006). O território é um lugar compartilhado no cotidiano, criador de raízes e laços de pertencimento e símbolos. É através do conhecimento desses símbolos que podemos restituir toda a riqueza de valores que dão sentido aos lugares e aos territórios de vida. São nesses territórios dinâmicos que encontramos 
e reconhecemos as sociologias das ausências, (re)criando e (re)construindo outros sentidos para a solidariedade e condição humana.

O território é visto como um campo de forças, uma teia, uma rede de relações sociais que, apesar de sua complexidade interna, define ao mesmo tempo um limite, uma alteridade: a diferença entre "nós" e os "outros". Territórios são relações sociais projetadas no espaço, uma rede de relações sociais e produtivas capazes de produzirem singularidades (SOUZA, 1995).

A ecologia dos saberes não concebe os conhecimentos em abstrato, mas como práticas de conhecimentos que possibilitam ou impedem certas intervenções no mundo real. Essas práticas se territorializam, criam redes de identidades e pertencimentos. O território, para SANTOS (2005), seria formado por redes de lugares. Essa compreensão valeria, segundo HISSA (2009), para as emoções, os sentimentos, a cooperação e a própria sociabilidade.

Assim, o movimento, fenômeno, ausências, saberes que trazemos para a discussão, como expressão silenciosa do desejo de compartilhar da dignidade da vida, do corpo do mundo, são algumas experiências de desenvolvimento de espaços de conhecimento e produção musical com populações marginalizadas do processo de desenvolvimento, na Bahia.

Em um levantamento recente, constatou-se a existência de 20 instituições baianas que desenvolvem trabalhos de ensino, educação musical, pesquisa e criação artística - ver Tabela 3. Nossa inquietação é: como esses movimentos se constituíram? Quais as contribuições para o desenvolvimento humano dessas pessoas, para a formação de territorialidades, espaços de emergência da criatividade, de dignidade, da busca permanente do novo; do sentido novo da vida numa cidade tão desigual como Salvador.

\section{4 - A Bahia contemporânea}

Da condição agro-mercantil à inserção no mundo pós-industrial, é a partir do setor terciário de sua economia que a Bahia é inserida no amplo e competitivo cenário nacional e internacional contemporâneo. Bahia que apresenta altos índices de concentração de sua produção na capital e nos municípios formadores de sua região metropolitana.

Dentro da mesma lógica do desenvolvimento da economia brasileira, a Bahia representaria assim a radicalização da face mais perversa desse modelo. Os dados oficiais e as estatísticas corroboram essa afirmativa, além de apontar que a trajetória de desenvolvimento econômico adotado, até então, tem oportunizado à capital baiana, altos índices de concentração de renda, pobreza, exclusão e violência. Em 2009, com uma população estimada em 2.998.056 (IBGE, 2010), Salvador apresenta uma incidência de pobreza de 35,76\%, índice de Gini 0,49 (IBGE, 2003).

A partir dos dados da Superintendência de Estudos Econômicos e Sociais da Bahia (SEI), o bairro da Pituba, por exemplo, com aproximadamente 200 mil pessoas, 
responde por $30 \%$ de toda a riqueza da cidade, correspondendo a $7,5 \%$ do total de moradores do município. No miolo da cidade, ficam os bairros mais pobres economicamente, como Cajazeiras, onde moram cerca de 300 mil pessoas $(11 \%$ da população), que fica com somente $2,8 \%$ da riqueza. É bem verdade que os números da SEI são de 2003, mas incluem uma projeção para 2013, onde a partir dos estudos e estatísticas, a concentração de renda tende a se agravar. Segundo o estudo, em 2013, a Pituba concentrará 35\% da riqueza de Salvador, enquanto Cajazeiras ficará com somente 2,1\%.

No campo da segurança pública, os dados também são preocupantes. Em 2008, a Secretaria de Segurança Pública do Estado da Bahia registrou 1.733 homicídios dolosos, o que corresponde a uma média mensal para este mesmo ano de 144 homicídios/mês, ou 36 homicídios/semana.

\begin{tabular}{|c|c|c|c|c|c|c|c|c|c|c|c|c|c|c|c|c|c|}
\hline REGISTROS & $\begin{array}{l}\text { AIS } \\
\text { P1 }\end{array}$ & $\begin{array}{l}\text { AIS } \\
\text { P2 }\end{array}$ & $\begin{array}{l}\text { AIS } \\
\text { P3 }\end{array}$ & $\begin{array}{l}\text { AIS } \\
\text { P4 }\end{array}$ & $\begin{array}{l}\text { AIS } \\
\text { P5 }\end{array}$ & $\begin{array}{l}\text { AIS } \\
\text { P6 }\end{array}$ & $\begin{array}{l}\text { AIS } \\
\text { P7 }\end{array}$ & $\begin{array}{l}\text { AIS } \\
\text { P8 }\end{array}$ & $\begin{array}{l}\text { AIS } \\
\text { P10 }\end{array}$ & $\begin{array}{l}\text { AlS } \\
\text { P12 }\end{array}$ & $\begin{array}{l}\text { AIS } \\
\text { P13 }\end{array}$ & $\begin{array}{l}\text { AIS } \\
\text { P16 }\end{array}$ & $\begin{array}{l}\text { AIS } \\
\text { P17 }\end{array}$ & $\begin{array}{l}\text { AIS } \\
\text { P18 }\end{array}$ & $\begin{array}{l}\text { AlS } \\
\text { P19 }\end{array}$ & $\begin{array}{l}\text { AIS } \\
\text { P20 }\end{array}$ & TOTAL \\
\hline Homicídio doloso & 9 & 41 & 67 & 94 & 88 & 73 & 133 & 3 & 141 & 65 & 245 & 224 & 127 & 177 & 106 & 140 & 1.733 \\
\hline $\begin{array}{l}\text { Tentativa de } \\
\text { homicídio }\end{array}$ & 6 & 24 & 43 & 71 & 66 & 55 & 78 & 8 & 69 & 44 & 187 & 127 & 23 & 110 & 62 & 60 & 1.033 \\
\hline Estupro & 6 & 6 & 5 & 17 & 43 & 6 & 16 & 9 & 22 & 6 & 26 & 35 & 4 & 31 & 19 & 32 & 283 \\
\hline $\begin{array}{l}\text { Roubo seguido de } \\
\text { morte }\end{array}$ & 0 & 0 & 0 & 5 & 1 & 0 & 0 & 0 & 1 & 5 & 4 & 3 & 1 & 9 & 3 & 0 & 32 \\
\hline $\begin{array}{l}\text { Roubo a ônibus } \\
\text { urbano }\end{array}$ & 50 & 162 & 139 & 98 & 224 & 15 & 122 & 59 & 229 & 126 & 136 & 233 & 64 & 212 & 109 & 224 & 2.202 \\
\hline Furto de veículo & 89 & 184 & 85 & 258 & 161 & 15 & 139 & 203 & 87 & 156 & 88 & 39 & 20 & 81 & 30 & 137 & 1.772 \\
\hline Roubo de veículo & 91 & 174 & 159 & 207 & 372 & 3 & 246 & 427 & 290 & 578 & 380 & 186 & 156 & 428 & 167 & 697 & 4.561 \\
\hline \multicolumn{18}{|l|}{$\begin{array}{l}\text { ATIVIDADE } \\
\text { POLICIAL }\end{array}$} \\
\hline Usuário de Drogas & 81 & 262 & 36 & 158 & 119 & 72 & 40 & 27 & 110 & 122 & 208 & 73 & 2 & 47 & 57 & 94 & 1.508 \\
\hline Veículos recuperados & 33 & 139 & 82 & 126 & 192 & 24 & 208 & 730 & 190 & 186 & 338 & 184 & 204 & 247 & 109 & 332 & 3.324 \\
\hline $\begin{array}{l}\text { Pessoas autuadas em } \\
\text { flagrante }\end{array}$ & 67 & 812 & 110 & 675 & 199 & 46 & 146 & 336 & 111 & 143 & 171 & 176 & 31 & 95 & 169 & 30 & 3.317 \\
\hline $\begin{array}{l}\text { Apreensão de arma } \\
\text { de fogo }\end{array}$ & 7 & 112 & 29 & 183 & 142 & 15 & 34 & 49 & 51 & 58 & 93 & 75 & 12 & 37 & 49 & 28 & 974 \\
\hline
\end{tabular}

Ex.1 - Tabela de registros de ocorrências policiais em Salvador - 2008 (SSP/BA, 2010)

Na Tabela 1, pode-se perceber que a Área Integrada de Segurança Pública (AISP) relacionada ao bairro de Cajazeiras - AISP 19 -, em 2008, totalizou 106 homicídios dolosos contra 03 no bairro da Pituba - AISP 8. O recorde de homicídios dolosos ficou com a AISP 13, que envolve os bairros de Narandiba, Doron, Tancredo Neves e Engomadeira, com 245 homicídios dolosos.

As estatísticas e dados oficiais, assim como os estudos de entidades e movimentos em prol dos direitos humanos, permitem afirmar que boa parte dos bairros centrais de Salvador, aqueles marcados por grandes contingentes populacionais, apresentam os maiores riscos à condição humana, realçando uma capital desigual e excludente para a maior parcela de sua população.

Dentro da perspectiva de SOUSA SANTOS (2009; 2007), o planejamento urbano regional, ao estimular e privilegiar as áreas "luminosas", os chamados espaços 
globais, também cria ausências a partir do local, do particular. Esses "espaços opacos", como aponta o autor, não teriam dignidade como alternativa crível a uma realidade global, universal. A preponderância da lógica da apropriação e violência gera o fascismo social, uma espécie de apartheid. Esta divisão é visível, principalmente, nos grandes centros urbanos brasileiros, e, em Salvador, não seria diferente.

Quanto às taxas de desemprego na capital baiana, as informações da Pesquisa de Emprego e Desemprego, realizada pela SEI em parceria com o Departamento Intersindical de Estatísticas e Estudos Socioeconômica (Dieese), Fundação Sistema Estadual de Análise e Dados (Seade) e Secretaria do Trabalho, Emprego, Renda e Esporte (Sete), apresentam aumento de 17,7\%, (janeiro/2010), para 18,8\% (fevereiro/2010), fenômeno já aguardado por conta do lançamento de jovens no mercado de trabalho, mas, também, justificado pela centralidade da capital baiana que atrai trabalhadores de outras regiões e municípios. Esse movimento expressa, também, a precariedade das oportunidades nas cidades médias e pequenas e a falta de políticas públicas direcionadas para a educação, saúde e valorização das histórias e culturas locais.

Os bairros soteropolitanos que abrigam as experiências musicais pesquisadas são: Candeal, Pelourinho, Cabula, Alagados, Fazenda Coutos, Vasco da Gama, Centro, Queimadinho, Liberdade, Tancredo Neves, Rio Vermelho, Campo Grande e Canela. $\mathrm{Na}$ região metropolitana de Salvador, a iniciativa captada é a Cidade do Saber, município de Camaçari, que também utiliza a música como elemento estéticopedagógico. Os bairros registrados neste estudo encontram-se dispersos pelo município de Salvador, caracterizando a dicotomia entre apropriação e violência, como nos informam as tabelas 1 e 2.

É importante ressaltar que a partir dos anos 1970, os Estados perdem a sua força como um dos atores mais relevantes da ação coletiva, se comparada à época do desenvolvimentismo. O poder de intervenção estratégica e definição das regras do jogo da ação política que definem e modificam os cenários das ações coletivas são minados pela força e interesse dos grupos internacionais. Com a liberalização das fronteiras, surgem jogos suplementares, novos papéis e regras desconhecidas, bem como novas contradições e conflitos. Nesse momento, cresce a participação das ONGs (organizações não governamentais) que passam a atuar em territórios e áreas sociais menos privilegiadas.

Essas instituições iniciam os trabalhos com essas comunidades, fundamentalmente, a partir da década de 1990, quando se radicaliza o processo de modernização capitalista sob a batuta do FMI, e acirram as desigualdades sociais e a violência. A defesa do Estado mínimo e a privatização dos serviços públicos fundamentais são expressões da radicalização do fascismo social, presente nos territórios de apropriação e violência.

A considerável desigualdade de renda em Salvador também se reflete na educação, destacando positivamente, mais uma vez, via $\mathrm{UDH}^{1}$, bairros litorâneos. Segundo o 
relatório do Programa das Nações Unidas para o Desenvolvimento - PNUD -, esta relação em Salvador pode ser compreendida:

Enquanto na UDH - ITAIGARA 97,67\% das crianças com idade entre 7 e 14 anos estão freqüentando o ensino fundamental, essa proporção é de $82,70 \%$ na UDH COUTOS-Fazenda Coutos, Felicidade e chega a $78,68 \%$ na UDH vizinha, COUTOS/ PERIPERI-Nova Constituinte, a com o menor índice. Há forte relação entre esses níveis de frequência e os índices de alfabetização. Enquanto a primeira tem o terceiro menor percentual de pessoas maiores de 15 anos analfabetas da região metropolitana $(0,93 \%)$ - atrás somente da UDH CAMINHOS DAS ÁRVORES-Iguatemi (0,47\%) e AMARALINA-Ubaranas $(0,70 \%)$, ambas em Salvador - a UDH - COUTOS-Fazenda Coutos, Felicidade tem 12,95\%. (PNUD/CONDER, 2006)

É possível perceber que avanços no nível de escolaridade, realçam consideravelmente as diferenças entre as UDHs. Se os bairros da Pituba e Itaigara apresentam 82,91\% dos adolescentes de 15 a 17 anos frequentando o ensino médio, o bairro de Fazenda Coutos registra 16,03\%. No nível superior, a distorção é ainda mais gritante. Nos dois primeiros bairros, o percentual de jovens com idade entre 18 e 24 anos matriculados em universidades/faculdades é de 59,64\% (PNUD/CONDER, 2006), enquanto Fazenda Coutos amarga apenas 0,37\% desta faixa etária populacional. Esses dados caracterizariam a segunda forma de apartheid, o fascismo contratual evidenciado a partir da precariedade dos serviços públicos e sua privatização.

Um exemplo emblemático das novas possibilidades sociais e econômicas, a partir da música, é o de Nayara Cruz Cerqueira, estudante do curso superior de licenciatura em música da Universidade Católica do Salvador. Atualmente com 26 anos, iniciou os estudos musicais em 2002, no LactoGirls - grupo de percussão feminina criado pela Lactomia (Associação Lactomia Ação Social - ver tabela III), localizado no bairro do Candeal Pequeno, em Salvador. Em 2003, passou a estudar e participar das atividades musicais desenvolvidas na Associação Pracatum de Ação Social,- ONG criada pelo músico e compositor Carlinhos Brown.

Em entrevista concedida no dia 14 de junho de 2010, Nayara Cruz, aponta sua participação nestes projetos como experiências fundamentais que a direcionaram para o ensino superior. Por problemas financeiros, já teve de trancar o curso superior em duas oportunidades, e atualmente custeia as mensalidades com recursos advindos de aulas particulares de música, cachês de shows como percussionista, trabalho regular como assistente administrativa na Escola Eraldo Tinôco ${ }^{2}$, além de, nos finais de semana, desempenhar atividades como panfletagem e distribuição de material publicitário sobre empreendimentos imobiliários da capital.

Com algumas viagens internacionais na carreira musical, Nayara Cruz Cerqueira, que sempre residiu em Cajazeiras, conheceu os projetos sociais que participou a partir de parentes que residiam no Candeal, e informa que, por diversas vezes, deixou de ensaiar e estudar por indisponibilidade financeira para deslocamentos, uma vez que não são bairros próximos. Cajazeiras é um bairro populoso e distante do centro de Salvador, e seus índices educacionais, vide tabela II, se representam diminuição nos números de analfabetos, também ofertam um quadro onde $66,42 \%$ 
CAStRO, A. A.; RIBEIRO M. T. F. Música e desenvolvimento em Salvador... Per Musi, Belo Horizonte, n.31, 2015, p.235-257.

da população entre 18 e 24 anos têm menos de onze anos de estudo, e apenas $0,54 \%$ deste contingente têm acesso ao ensino superior. 


\begin{tabular}{|c|c|c|c|c|c|c|c|c|c|c|c|c|c|c|c|}
\hline UDH & Código & $\begin{array}{c}\% 18 \text { a } 24 \\
\text { anos } \\
\text { analfabetas } \\
(1991)\end{array}$ & $\begin{array}{c}\% 18 \text { a } 24 \\
\text { anos } \\
\text { analfabetas } \\
(2000)\end{array}$ & $\begin{array}{c}\% 18 \text { a } \\
24 \\
\text { anos } \\
\text { com } \\
\text { menos } \\
\text { de } \\
\text { quatro } \\
\text { anos } \\
\text { de } \\
\text { estudo } \\
\text { (1991) }\end{array}$ & $\begin{array}{c}\% 18 \text { a } \\
24 \\
\text { anos } \\
\text { com } \\
\text { menos } \\
\text { de } \\
\text { quatro } \\
\text { anos } \\
\text { de } \\
\text { estudo } \\
(2000)\end{array}$ & $\begin{array}{c}\% 18 \text { a } \\
24 \\
\text { anos } \\
\text { com } \\
\text { menos } \\
\text { de oito } \\
\text { anos } \\
\text { de } \\
\text { estudo } \\
\text { (1991) }\end{array}$ & $\begin{array}{c}\% 18 \text { a } \\
24 \\
\text { anos } \\
\text { com } \\
\text { menos } \\
\text { de oito } \\
\text { anos } \\
\text { de } \\
\text { estudo } \\
(2000)\end{array}$ & $\begin{array}{c}\% 18 \text { a } \\
24 \\
\text { anos } \\
\text { com } \\
\text { menos } \\
\text { de } \\
\text { onze } \\
\text { anos } \\
\text { de } \\
\text { estudo } \\
\text { (1991) }\end{array}$ & $\begin{array}{c}\% 18 \text { a } \\
24 \\
\text { anos } \\
\text { com } \\
\text { menos } \\
\text { de } \\
\text { onze } \\
\text { anos } \\
\text { de } \\
\text { estudo } \\
(2000)\end{array}$ & $\begin{array}{c}\% 18 \text { a } \\
24 \\
\text { anos } \\
\text { com } \\
\text { doze } \\
\text { anos } \\
\text { ou } \\
\text { mais } \\
\text { de } \\
\text { estudo } \\
(1991)\end{array}$ & $\begin{array}{c}\% 18 \text { a } \\
24 \\
\text { anos } \\
\text { com } \\
\text { doze } \\
\text { anos } \\
\text { ou } \\
\text { mais } \\
\text { de } \\
\text { estudo } \\
(2000)\end{array}$ & $\begin{array}{c}\% 18 \text { a } \\
24 \text { anos } \\
\text { no } \\
\text { curso } \\
\text { superior } \\
(1991)\end{array}$ & $\begin{array}{c}\% 18 \text { a } \\
24 \text { anos } \\
\text { no } \\
\text { curso } \\
\text { superior } \\
(2000)\end{array}$ & $\begin{array}{c}\% 18 \text { a } \\
24 \text { anos } \\
\text { com } \\
\text { acesso } \\
\text { ao } \\
\text { curso } \\
\text { superior } \\
(1991)\end{array}$ & $\begin{array}{c}\% 18 \text { a } \\
24 \text { anos } \\
\text { com } \\
\text { acesso } \\
\text { ao } \\
\text { curso } \\
\text { superior } \\
(2000)\end{array}$ \\
\hline $\begin{array}{l}\text { ÁGUAS CLARAS / } \\
\text { CAJAZEIRAS } \\
\text { (Cajazeiras V,VI e VII) }\end{array}$ & 89 & 7,65 & 1,20 & 16,83 & 7,32 & 46,99 & 35,13 & 81,34 & 66,42 & 2,79 & 0,23 & 0,92 & 0,54 & 1,26 & 0,54 \\
\hline ÁGUAS CLARAS & 88 & 5,93 & 3,12 & 18,13 & 11,85 & 59,98 & 45,96 & 88,36 & 83,40 & 0,33 & 2,11 & 0,33 & 1,41 & 0,33 & 1,41 \\
\hline $\begin{array}{l}\text { CAJAZEIRAS/FAZ GRANDE } \\
\text { (Cajazeiras VIII, Faz Gde II e } \\
\text { III) }\end{array}$ & 82 & 0,59 & 2,59 & 10,75 & 11,13 & 54,19 & 48,62 & 85,02 & 80,04 & 3,21 & 1,03 & 0,90 & 1,50 & 0,90 & 1,50 \\
\hline $\begin{array}{l}\text { CAJAZEIRAS } \\
\text { (Cajazeiras X e XI) }\end{array}$ & 90 & 2,92 & 0,33 & 14,68 & 8,19 & 53,10 & 35,40 & 79,29 & 77,74 & 2,85 & 1,73 & 2,35 & 1,16 & 2,35 & 1,16 \\
\hline $\begin{array}{l}\text { FAZENDA GRANDE } \\
\text { (Fazenda Grande I e II) }\end{array}$ & 94 & 2,81 & 2,76 & 14,00 & 8,49 & 48,75 & 27,97 & 80,58 & 69,29 & 0,42 & 1,43 & 0,42 & 2,29 & 0,42 & 2,29 \\
\hline $\begin{array}{l}\text { FAZENDA GRANDE } \\
\text { (Fazenda Grande III e IV) }\end{array}$ & 93 & 2,22 & 1,87 & 9,34 & 6,86 & 41,60 & 30,50 & 78,17 & 71,02 & 2,05 & 0,86 & 2,87 & 1,34 & 2,87 & 1,34 \\
\hline XIV - CAJAZEIRAS & 14 & 4,09 & 2,03 & 14,49 & 9,03 & 50,82 & 37,41 & 81,95 & 74,67 & 1,85 & 1,23 & 1,31 & 1,38 & 1,38 & 1,38 \\
\hline $\begin{array}{l}\text { REGIÃO METROPOLITANA } \\
\text { DE SALVADOR }\end{array}$ & & 6,43 & 3,08 & 18,56 & 12,27 & 53,07 & 41,31 & 76,92 & 70,08 & 5,30 & 6,66 & 5,05 & 7,82 & 5,36 & 8,09 \\
\hline
\end{tabular}

Ex.2 - Tabela Nível de Educação no bairro de Cajazeiras (PNUD/CONDER, 2011).

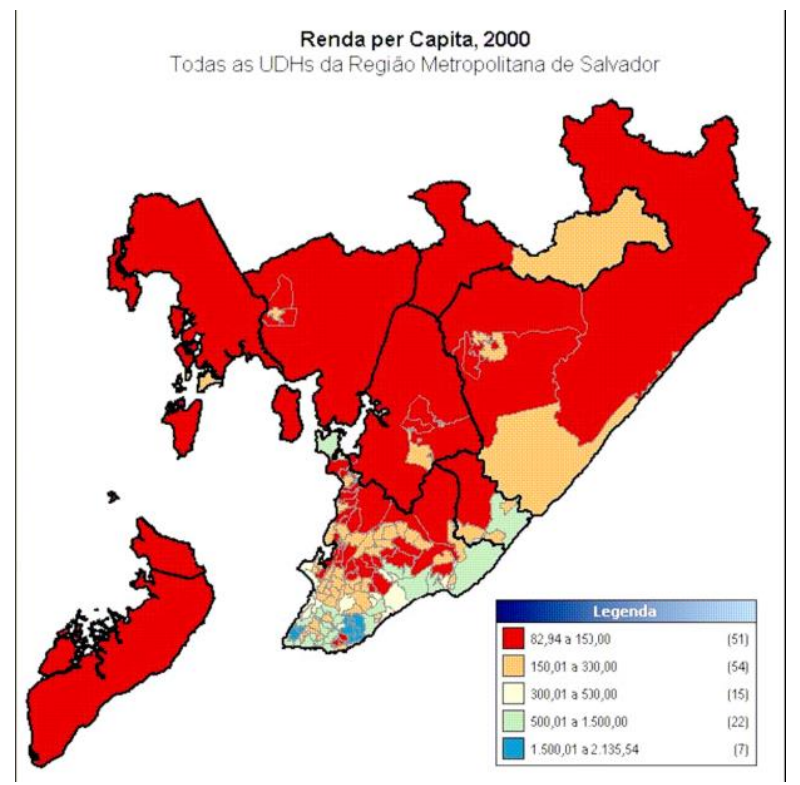

Ex.3 - Quadro da Renda por UDH em Salvador (PNUD/CONDER, 2011). 


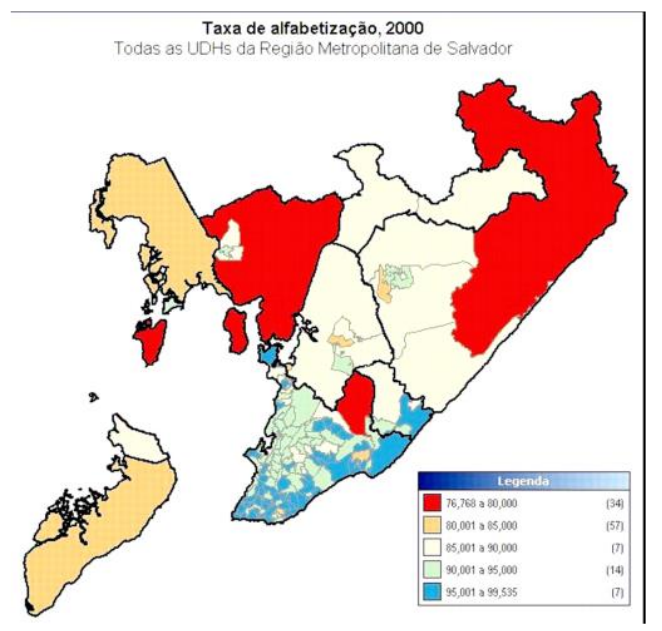

Ex.4 - Quadro da alfabetização por UDH em Salvador (PNUD/CONDER, 2011).

\section{5 - 0 desenvolvimento e as sonoridades emergentes}

Se a concentração do acesso à educação, das atividades produtivas e da riqueza em Salvador, assim como seus próprios registros internos de desigualdade oportunizam externalidades negativas, também é possível perceber mudanças de comportamento, questionamentos acerca da relação homem/capital, da díade tempo-espaço, da oferta de outras possibilidades de (con)vivência humana a partir do sonho, do subjetivo, do conhecimento, e, principalmente, da música como elemento de (res)significação do sentido da vida.

Uma transformação silenciosa, mas significativa, a partir da educação musical oportunizada por organizações não governamentais (ONGs), organizações sociais, instituições sem fins lucrativos, escolas públicas, além de programas e projetos relacionados a órgãos governamentais. Enquanto prática presente no cotidiano de milhares de pessoas e da própria cidade, pode-se compreender, a partir dos exemplos discriminados abaixo, o valor da dignidade humana como valor ético intercultural (SOUSA SANTOS, 1995) que também transcende os modelos organizacionais, reiterando a limitação do mercado (RAMOS, 1989).

A multidimensionalidade registrada a partir da diversidade de organizações inscritas na Tabela III acaba por ressaltar a necessidade de se repensar novas dimensões para o modelo de desenvolvimento para a cidade do Salvador, a partir de valores mais integrativos, tolerantes, e compreensíveis à própria diversidade, "(...) onde o homem se empenha em tipos nitidamente diferentes, embora verdadeiramente integrativos, de atividades substantivas" (RAMOS, 1989, p.140). Ainda para este autor, o modelo multidimensional expande a noção de recursos e de produção, considerando atividades remuneradas e não remuneradas, produção econômica e produções de outra natureza. O pressuposto basilar do modelo proposto por este autor supõe que para alcançar a sua atualização pessoal, o indivíduo deve procurar se libertar da dependência do mercado - este último, enquanto detentor de emprego. Não se trata, assim, de abandonar o modelo de produção vigente, mas de pensar novas possibilidades produtivas, menos injustas, dentro dele. 


\begin{tabular}{|c|c|c|c|c|}
\hline Instituição & Natureza & $\begin{array}{c}\text { Fundação } \\
\text { Oficial }\end{array}$ & Bairro & Objetivos/Características \\
\hline Associação Lactomia Ação Social & ONG & 2003 & $\begin{array}{l}\text { Candeal } \\
\text { Pequeno } \\
\end{array}$ & $\begin{array}{l}\text { Utilização de materiais reaproveitados do lixo, e a transformação destes em } \\
\text { instrumentos de percussão, figurino e cenário. O objetivo do grupo é levar a } \\
\text { sociedade à reflexão sobre cidadania e responsabilidade ambiental, através de } \\
\text { composições que retratam temas e dificuldades da situação mundial. }\end{array}$ \\
\hline $\begin{array}{l}\text { Centro de Educação Profissional } \\
\text { Pracatum/Escola Pracatum }\end{array}$ & ONG & 1995 & $\begin{array}{l}\text { Candeal } \\
\text { Pequeno }\end{array}$ & $\begin{array}{l}\text { Educação musical e tecnologia como elementos de inclusão social. Cursos } \\
\text { profissionalizantes em diversas áreas da arte musical, como mixagem, gravação } \\
\text { digital, percussão, captação de áudio para cinema e TV, entre outras. }\end{array}$ \\
\hline Eletrocooperativa & ONG & 2003 & Pelourinho & $\begin{array}{l}\text { Ofertar humanização para o processo de inclusão digital, a partir da transformação } \\
\text { do computador em instrumento musical. Atualmente conta com dois escritórios } \\
\text { Salvador e São Paulo. Em Salvador, a parte operacional dos cursos, oficinas } \\
\text { dmais atividades. Em São Paulo, concentra-se a captação de recursos e } \\
\text { relacionamento institucional com os parceiros. }\end{array}$ \\
\hline Didá Escola de Música Feminina & ONG & 1993 & Pelourinho & $\begin{array}{l}\text { Instituição cultural e sem fins lucrativos que tem o objetivo de elevar a qualidade de } \\
\text { vida das pessoas através da música. Fundado por Neguinho do Samba, a educação } \\
\text { musical oferta cursos para os instrumentos de cordas, sopro, teclado, percussão } \\
\text { canto, capoeira, dança afro, teatro, artes, inglês e informática. Possui três projetos } \\
\text { Didá Banda Feminina, Sódomo e o bloco de carnaval. Atende atualmente cerca de } \\
200 \text { jovens. }\end{array}$ \\
\hline Grupo Cultural Olodum / Escola Olodum & ONG & 1979 & Pelourinho & $\begin{array}{l}\text { Criado como bloco carnavalesco em 1979, a partir de } 1983 \text { dá início a outras } \\
\text { atividades, e, dentre elas, a Escola Olodum. Destaque para seu projeto pedagógico } \\
\text { de conteúdo multiétnico e multicultural, possuindo uma grade curricular pluricultura } \\
\text { envolvendo diversas linguagens musicais, coral e dança afro e da inclusão cultural } \\
\text { digital. Em paralelo, também destacam-se questões como cidadania e diversidade } \\
\text { étnica, por meio de Workshops de Formação de Lideranças Afro-descendentes } \\
\text { campanhas de mobilização social. Parceiros nacionais e internacionais em sua } \\
\text { proposta pedagógica que alia tecnologia à qualificação profissional no campo } \\
\text { musical. }\end{array}$ \\
\hline Projeto Axé & ONG & 1990 & Comércio & $\begin{array}{l}\text { Através da figura do educador de rua, estimula permanentemente os jovens a } \\
\text { construírem um projeto de vida novo e renovador, onde estes passam a s } \\
\text { reconhecer não apenas como Sujeitos de Direto, mas também, Sujeitos de Desejo. } \\
\text { Em } 20 \text { anos de existência passaram pelo Axé mais de } 13.700 \text { crianças } \\
\text { adolescentes. }\end{array}$ \\
\hline $\begin{array}{l}\text { Escola de Educação Percussiva Integral } \\
\text { (EEPI) }\end{array}$ & ONG & 2007 & Cabula & $\begin{array}{l}\text { Educar, através da música, jovens em risco social e pessoal, para melhol } \\
\text { qualificação na sociedade. }\end{array}$ \\
\hline Grupo Cultural Bagunçaço & ONG & 1991 & Alagados & $\begin{array}{l}\text { Objetiva atender e promover os direitos da criança, do adolescente e do jovem } \\
\text { através de atividades artísticas, educacionais e socioculturais. Atividades como } \\
\text { oficina de percussão, dança, arte com reciclados, literatura, bem como seminários } \\
\text { palestras e cursos profissionalizantes. Percussão e Reciclagem, mas também aulas } \\
\text { de música percussiva, filarmônica e, mais recentemente, a TV Lata. }\end{array}$ \\
\hline Instituto de Música da UCSal (IMUCSal) & $\begin{array}{l}\text { Universidade } \\
\text { (Extensão) }\end{array}$ & 1989 & Centro & $\begin{array}{l}\text { Através da Oficina de Criatividade Infanto-Juvenil, desde } 1989 \text { desenvolve-se neste } \\
\text { Instituto diversos cursos gratuitos em musicalização infantil e artes plásticas. O } \\
\text { Projeto já atendeu mais de } 1.500 \text { crianças e adolescentes. }\end{array}$ \\
\hline Escola Técnica Estadual Luiz Navarro de Brito & Rede Estadual de & 2002 & Queimadinho & $\begin{array}{l}\text { Escola da Rede Estadual de Educação, onde a música é um elemento de } \\
\text { socialização e inclusão sociocultural. A partir do interesse de sua atual gestora } \\
\text { disponibiliza amplo e equipado estúdio de ensaio, instrumentos musicais de cordas }\end{array}$ \\
\hline
\end{tabular}

PER MUSI - Revista Acadêmica de Música - n.31, 353p., jan. - jun., 2015 Recebido em: 16/04/2014 - Aprovado em: 14/06/2014 


\begin{tabular}{|c|c|c|c|c|}
\hline & Ensino & & & $\begin{array}{l}\text { sopro, além de fomentar a criação de grupos musicais locais. Procura estabelecer } \\
\text { parcerias com as Universidades que enviam estagiários de música. }\end{array}$ \\
\hline Fundação Pierre Verger & ONG & 1988 & $\begin{array}{l}\text { Av. Vasco da } \\
\text { Gama }\end{array}$ & $\begin{array}{l}\text { A partir do Espaço Cultural Pierre Verger, a Fundação oferece gratuitamente } 15 \\
\text { oficinas para crianças e jovens, com temáticas que abordam a cultura afro-brasileira, } \\
\text { música e a cidadania. No campo musical, destaque para Orquestra Experimental, } \\
\text { Experimentação musical, Violão, Teclado e Percussão. }\end{array}$ \\
\hline TV Pelourinho & ONG & 2008 & Pelourinho & $\begin{array}{l}\text { Possibilitar através de oficinas a formação de jovens em funções técnicas capazes } \\
\text { de facilitar a inserção no mercado de trabalho no campo do audiovisual. A música, } \\
\text { como conteúdo transversal, integra temáticas das produções audiovisuais dos } \\
\text { alunos. Atende } 400 \text { jovens/ano. }\end{array}$ \\
\hline Bloco Afro llê Aiyê & ONG & 1974 & Liberdade & $\begin{array}{l}\text { A Escola de Percussão, Canto e Dança Band'Erê, foi criada no final da década de } \\
\text { oitenta para renovar os quadros artísticos da Band'Aiyê. A partir de } 1995 \text { torna-se } \\
\text { uma escola de formação integral para a cidadania, a partir da identidade racial, do } \\
\text { pensamento crítico e da auto-estima. }\end{array}$ \\
\hline Ceifar & ONG & 1994 & $\begin{array}{l}\text { Tancredo } \\
\text { Neves }\end{array}$ & $\begin{array}{l}\text { Surgiu da observação e avaliação dos problemas sociais dessa comunidade tendo } \\
\text { como ponto de partida o planejamento familiar através de visitas e encontros de } \\
\text { formação sobre sexualidade, a promoção de atividades lúdico-educativas, trazendo } \\
\text { para a comunidade uma perspectiva de melhoria nas condições de vida. A educação } \\
\text { musical é desenvolvida a partir do ensino da teoria musical aliada à formação de } \\
\text { coral. Atende cerca de } 490 \text { crianças e jovens. }\end{array}$ \\
\hline Oficina de Música Instrumental & ONG & 2008 & Canela & $\begin{array}{l}\text { Oferece a crianças e jovens de escolas públicas de Salvador a possibilidade de } \\
\text { conhecer a história do Trio Elétrico e de aprender a tocar guitarra baiana, violão, } \\
\text { bateria, percussão ou baixo elétrico, que constituem a base instrumental para a } \\
\text { formação de um músico de Trio Elétrico. }\end{array}$ \\
\hline Neojibá & $\begin{array}{l}\text { Organização } \\
\text { Social - } \\
\text { SECULT/Ba }\end{array}$ & 2007 & $\begin{array}{l}\text { Campo } \\
\text { Grande }\end{array}$ & $\begin{array}{l}\text { Programa de formação de núcleos de orquestras e corais infanto-juvenis no Estado } \\
\text { da Bahia, visando a excelência e a integração social por meio da prática coletiva da } \\
\text { música. Sua estratégia está focada na construção ética e pedagógica da infância e } \\
\text { da juventude, mediante a instrução e a prática orquestral e coral, capacitação em } \\
\text { ensino musical, novas tecnologias e na reparação de instrumentos musicais. }\end{array}$ \\
\hline Cidade do Saber & $\begin{array}{l}\text { Organização } \\
\text { Social }\end{array}$ & 2007 & $\begin{array}{l}\text { Cidade de } \\
\text { Camaçari } \\
\text { (BA) }\end{array}$ & $\begin{array}{l}\text { Propõe a prática musical de repertório popular e erudito, a leitura musical e o } \\
\text { constante aperfeiçoamento técnico. Busca desenvolver habilidades específicas para } \\
\text { a execução, sempre dentro de um contexto de compreensão das estruturas da } \\
\text { linguagem e se colocando num permanente relacionamento com as particularidades } \\
\text { próprias de cada instrumento. Dentre os cursos, Violão, Contrabaixo, Percussão, } \\
\text { Teclado, Canto Coral e Bateria. }\end{array}$ \\
\hline Hora da Criança & ONG & 1943 & $\begin{array}{l}\text { Parque } \\
\text { Lucaia }\end{array}$ & $\begin{array}{l}\text { Fundada pelo professor, jornalista, advogado e teatrólogo Adroaldo Ribeiro Costa, } \\
\text { oferta aulas de música, dança, teatro e artes visuais, além de iluminação cênica e } \\
\text { cenografia. Atualmente atende cerca de } 400 \text { alunos/ano, desenvolvendo suas } \\
\text { atividades em parceria com as redes estadual e municipal de educação. }\end{array}$ \\
\hline Colégio Estadual Deputado Manoel Novaes & Rede Estadual & 1993 & Canela & Curso Técnico Profissionalizante em Execução Instrumental. \\
\hline PIM - Projeto de Iniciação Musical & Instituto & 1995 & $\begin{array}{l}\text { Fazenda } \\
\text { Coutos }\end{array}$ & $\begin{array}{l}\text { Um dos projetos vinculados à Associação dos Educadores da Escola Comunitária } \\
\text { São Miguel. Atualmente encontra-se sob a coordenação do IOAO - Instituto } \\
\text { Otaviano Almeida Oliveira. Desenvolve projetos artísticos-culturais a partir da } \\
\text { música e da recriação dos folguedos populares. Em } 2009 \text {, com o espetáculo Donos } \\
\text { da Terra, recebeu o Prêmio Braskem nas categorias Melhor Espetáculo Infanto- } \\
\text { juvenil e Melhor Diretor (João Gonzaga). Em } 15 \text { anos, os registros apontam para } \\
\text { atendimento a } 5.000 \text { criancas e jovens. }\end{array}$ \\
\hline
\end{tabular}

Ex.5 - Tabela III - Música e Gestão Social

PER MUSI - Revista Acadêmica de Música - n.31, 353p., jan. - jun., 2015 Recebido em: 16/04/2014 - Aprovado em: 14/06/2014 
Neste sentido, a educação musical oferecida pelas instituições aqui citadas ${ }^{3}$, não raro, vêm acompanhadas de orientação profissional, mas, principalmente, de conteúdo e discussões acerca da necessidade de reflexão acerca do modelo de desenvolvimento hegemônico, objetivando, ainda, um mundo mais humanizado a partir de pequenos e grandes gestos no cotidiano, tal como a desconcentração de renda, conhecimento, tecnologia, entre outros. É importante lembrar, como afirma SOUSA SANTOS (2002), que a globalização neoliberal é apenas uma das formas de globalização, dominante e hegemônica, mas não a única. Essa lógica é confrontada por outras formas alternativas, contra-hegemônicas, que podem sinalizar novos caminhos de desenvolvimento. Há uma crise do conhecimento, dos instrumentos políticos e da forma de fazer política. É nesse sentido que a crise abre espaços para a reformulação da própria forma de produzir conhecimento e sociabilidade.

A partir do breve relato de algumas dessas experiências, pretendemos olhar e compreender a singularidade dos processos e a complexidade das dimensões envolvidas, em que a música é apenas a atividade organizadora, potencializadora de novas formas de realização e direcionamento do sentido da vida.

\section{1 - Sonoridades emergentes: O Neojibá}

Criado pelo pianista e maestro baiano Ricardo Castro, o Neojibá é configurado como um amplo programa governamental de formação de núcleos de orquestras e corais infanto-juvenis no Estado da Bahia, visando a excelência e a integração social por meio da formação de crianças e jovens sem distinção de classe social a partir da prática coletiva da música.

No caso do Neojibá - Núcleos Estaduais de Orquestras Juvenis e Infantis da Bahia -, que prioriza turnês no interior do Estado, por exemplo, os primeiros alunos se tornaram multiplicadores, e estão iniciando a disseminação do conhecimento. $O$ primeiro núcleo da Neojibá fora de Salvador será em Simões Filho, no Centro Educacional Santo Antônio (CESA), ligado às Obras Sociais Irmã Dulce.

A implantação do Neojibá foi desenvolvida em intercâmbio com a FESNOJIV (Fundación Del Estado para El Sistema Nacional de las Orquestas Juveniles de Venezuela), e seu "El Sistema", implantado há 35 anos e hoje mundialmente aclamado como uma das mais bem sucedidas experiencias de formação orquestral no mundo. Em dezembro de 2009, a gestão do NEOJIBÁ foi transferida para a primeira Organização Social de Cultura no âmbito do Estado, a AOJIN, que passa a receber os recursos governamentais à medida que executa as metas pactuadas no Plano de Trabalho do Contrato de Gestão. A estratégia adotada possibilita a contratação de profissionais com menor incidência da burocracia estatal, convite a profissionais estrangeiros, e a desvinculação das atividades do Neojibá do calendário político.

\subsection{Sonoridades emergentes: A Eletrocooperativa}

Outro exemplo a ser destacado é o da Eletrocooperativa, fundada em 2003, no Pelourinho. Aliando educação, música e tecnologia, já formou 930 jovens - não 
contando a turma atual -, a partir do Hip Hop e de um discurso criativo que contempla, inclusive, uma metodologia original, a Sevirologia, que significa "se virar para vir-a-ser". A partir do sítio eletrônico da Eletrocooperativa, a definição de Sevirologia é justificada

\begin{abstract}
Vem da expressão "se virar": quando a gente se vira, fortalecemos nosso ser e nos encontramos com a nossa própria sabedoria. Isso traz uma nova forma de olhar para a vida, nos traz uma mudança de perspectiva, fortalece nossa autoestima porque percebemos que somos capazes de fazer o melhor com aquilo que temos. O sevirólogo aprende sozinho e com os outros para construir seus caminhos sempre por meio da ação em busca da transformação. É um ser integral com quatro dimensões: a política, a ambiental, a cultural e a econômica.
\end{abstract}

A produção dos jovens da Eletrocooperativa é diretamente acompanhada pelo verbo disponibilizar. Neste caso, na rede mundial de computadores, através de portal próprio e utilizando as licenças creative commons. A evolução do processo de formação dos jovens, num segundo momento, identificou a necessidade de geração de renda, o que fez surgir em 2006, a Usina de Produção.

A sede da Eletrocooperativa, localizada no Pelourinho, Centro Histórico de Salvador, agrega estúdio musical, ilhas de edição, salas da administração, computadores com programas de edição de áudio e vídeo. Nas paredes, quadros e pinturas em grafites de artistas locais, com desenhos e palavras que expressam o(s) sentido(s) de participar da Eletrocooperativa. Quem adentra a sede, se depara com um destes registros onde as palavras e expressões escolhidas são "alegria", "generosidade", "prazer em servir", "ser digital", "desapego", "transparência", "flexibilidade", "honestidade", "coletividade", "coragem" e "espiritualidade".

Uma das primeiras alunas da Eletrocooperativa, hoje monitora e assistente administrativa, Jaqueline Reis, acredita que o sucesso da ONG, a partir da considerável demanda e visibilidade de suas ações, é justificado pela oportunidade de apresentar opções de sobrevivência e sustentabilidade para jovens de comunidades periféricas de Salvador, via música e tecnologia. Informa ainda que "[...]a Eletrocooperativa já formou centenas de jovens que estão atuando profissionalmente no mercado, e trabalhando com qualidade e engajamento social em suas comunidades de origem".

\title{
5.3 - Sonoridades emergentes: O Bagunçaço
}

O Grupo Cultural Bagunçaço foi fundado em 1992, no bairro de Alagados - subúrbio ferroviário de Salvador -, integra em seu currículo 23 turnês internacionais, onde apresenta os resultados dos seus projetos de educação que envolvem a música a partir da percussão e de pequenos grupos de filarmônicas. Um elemento característico de suas atividades é a criação e utilização de instrumentos musicais percussivos feitos com elementos recicláveis. Lixo que vira instrumento, que se transforma em música e inclusão social para centenas de jovens.

O músico soteropolitano Joselito Crispim, um dos fundadores da ONG responsável pelo Bagunçaço, reitera inúmeras vezes que é a música quem lhe oportuniza ser uma pessoa "do bem", feliz e diferenciada. Para os jovens integrantes do Bagunçaço, ainda segundo Joselito Crispim, a música representa poder participar do 
cotidiano de Salvador de forma mais digna, mais humana, com mais auto-estima, pois o reconhecimento tem sido pela arte, e não pelas convenções sociais e modelos desiguais e excludentes.

Uma das iniciativas do Grupo Cultural Bagunçaço é a TV Lata, onde os alunos já estão aprendendo a produzir conteúdo audiovisual, pesquisar estéticas que contemplem, no vídeo, o conceitual e a mensagem do Bagunçaço.

\section{6 - Considerações Finais}

Esse artigo se insere no debate sobre o desenvolvimento, assim como das contribuições recentes que procuram ampliar e criticar a compreensão deste numa perspectiva linear e de progresso. A complexidade do tema nos motivou a refletir sobre um campo que vem abrindo possibilidades de inserção social e compreensão crítica do processo de exclusão socioespacial. Não temos, entretanto, a visão de que essas experiências sejam soluções para o sentido maior do desenvolvimento capitalista brasileiro, ou do subdesenvolvimento, pois, para isso, seriam necessárias reconfigurações estruturais. Mas, acreditamos que todos os campos de possibilidades, sejam elas científicas, artísticas e humanitárias precisam ser contempladas e acolhidas numa perspectiva de ampliação positiva da condição humana.

As propostas e o referido debate são complexos, e corremos o risco de algumas simplificações e não aprofundamento das questões teóricas e suas consequências. Mas são propostas em construção, abertas, e só o debate e aprofundamento das pesquisas sobre as diversas formas de economias e sociabilidades é que darão pistas sobre as potencialidades de novos caminhos de desenvolvimento. É necessário conhecer como as ausências são produzidas e explicitar suas especificidades, assim como refletir acerca das alternativas de transformação e envolvimento na perspectiva da produção de valor social. Olhamos e buscamos compreender aqui, de forma breve, o campo da música.

Impossível, neste trabalho, dar conta pormenorizada das ações desenvolvidas por cada instituição que tem a música como elemento estético-pedagógico relevante na transformação social dos cidadãos. Ainda assim, é relevante o registro de que estas iniciativas contemplam milhares de crianças e jovens baianos, soteropolitanos em sua maioria, que acreditam em outros caminhos para a condição humana, realizando-os. Seres humanos que sonham, agem e transformam as realidades impostas por modelos e propostas de modernidade ainda não concretizadas para a maioria da população de Salvador.

Crianças e jovens que sonham com música, com novas possibilidades de futuro. Futuro que contemple o subjetivo, o colaborativo, a racionalidade substantiva, a pluralidade que também envolve modelos econômicos. De forma realista e crítica, é possível afirmar que não há excludência, nem utopia neste sonho. O sonho é de estarem incluídos socialmente.

Não pretendemos sinalizar alternativas para o atual modelo de desenvolvimento, apenas alertar para a relevância que as atividades das organizações mencionadas, 
frequentemente silenciosas, vão tomando espaço a partir das artes, em especial a música, e criando novos sentidos de sociabilidade, fundamental para se pensar em uma cidade menos violenta, mais justa, ainda que a arte não seja a saída para todos os problemas sociais, mas, como afirma aponta HAESBAERT (2006, p.39), o território cultural precede o território político, e precede o espaço econômico. Isso significa que esses territórios das experiências musicais podem ser sinais de novos territórios de desenvolvimento, de novos desenvolvimentos... É preciso atentar para a pluralidade das possibilidades, pois não há uma única lógica de desenvolvimento, nem de globalização. Ainda que hegemônicas, é possível pensar novos caminhos...

A cidade de Salvador, para muito além das propagandas políticas e turísticas, nas últimas décadas registrou as tensões fundamentais diretamente relacionadas ao modelo de desenvolvimento capitalista. Como consequência, não menos direta, o aumento dos níveis de pobreza, o agravamento da concentração de renda, mas também o acirramento das questões ambientais numa capital que, em diversas unidades de análise, não registra planejamento, e vem sofrendo com a força do capital que avança ante a fragilidade de projetos políticos de poder que se revezam.

Nesse contexto, as experiências cartografadas podem ser caracterizadas como sinais, pistas de territórios emergentes de outras lógicas, de um novo sentido de sociabilidade. Mas para que esses sinais se tornem visíveis, ainda há muito a ser conquistado, como espaços de expressões de dignidade, criatividade e afetividade. Isso significa que essas forças emergentes precisam se tornar mais visíveis numa nova cartografia, mais equilibrada, justa e incorporada, também, por uma ação estratégica do Estado.

\section{Referências}

BENKO, G. Territoire et Sciences Sociales. In: ITÇAINA, X., PALARD, J. Régimes territoriaux et développement économique. Rennes: Presses Universitaires de Rennes II, Collection Espaces et Territoire, 2007.

PROGRAMA DAS NAÇÕES UNIDAS PARA O DESENVOLVIMENTO - PNUD; Companhia de Desenvolvimento Urbano do Estado da Bahia - CONDER. Atlas do Desenvolvimento Humano da Região Metropolitana de Salvador. Salvador: PNUD; CONDER; Fund. João Pinheiro, 2006.

DUPAS, G. O poder dos atores e a nova lógica econômica global. (mimeo.) Ensaio apresentado na Conferência Brasil e União Européia Ampliada. Rio de Janeiro: setembro de 2004.

O Impasse Ambiental e a lógica do capital. In: Meio ambiente e crescimento econômico; tensões estruturais. DUPAS, G. (Org). São Paulo: Unesp. 2009.

ESCOBAR, Arturo. Economics and the space of modernity: tales of market, production and labour. In: Cultural Studies, v. 19, n. 2, mar. 2005, p.130-175. Disponível em <http://www.unc.edu/ aescobar/> Acesso em 04/07/2007.

FRANÇA FILHO, Genauto C. Terceiro setor, economia social, economia solidária e economia popular: traçando fronteiras conceituais. In: Bahia Análise e Dados. Salvador: SEl/Governo da Bahia, 2002 v.12, n.1, Jun/2002.

HAESBAERT, Rogério. O mito da desterritorialização: do fim dos territórios à multiterritorialidade. Rio de Janeiro: Bertrand Brasil, 2006. 
HARVEY, David. Pensador marxista inglês fala sobre os rumos da economia mundial (Entrevista com Elizabeth Carvalho). Globo News - programas Milênio. Recuperado em 15 de abril, 2010, de http://globonews.globo.com/Jornalismo/GN/0,,MUL1567340-17665-314,00.html

O "novo"imperialismo: acumulação por espoliação. In: PANITCH, L e COLIN, L. (orgs). Socialist register 2004: o novo desafio imperial. Buenos Aires: Consejo Latinoamericano de Ciências Sociais - CLASCO, 2006.

HISSA, Cássio E. V. A mobilidade das fronteiras: inserções da geografia na crise da modernidade. Belo Horizonte: Editora UFMG, 2002. 316 p.

Territórios de diálogos possíveis. In: In: RIBEIRO, M.T.F. E MILANI, C.R.S (Org), Compreendendo a Complexidade socioespacial contemporânea: o território como categoria de diálogo interdisciplinar. Salvador: EDUFBA, 2009

LATOUCHE, Serge. Survivre au développement. De la décolonisation de l'imaginaire économique à la construction d'une société alternative. Paris: éditions Mille et Une Nuits, 2004.

LATOUR, Bruno. Politiques de la nature: comment faire entrer les sciences en démocratie. Paris: Découverte/Poche, 2004. 383 p.

LEFF, Enrique. Géopolitique de la biodiversité et développement durable. In: Alternatives sud: Changements climatiques impasses et perspectives. Points de vue du Sud. v. 13-2006/2.

MENESES. Maria Paula. Agentes do conhecimento? A consultoria e a produção do conhecimento em Moçambique. In: SOUSA SANTO, Boaventura (org). Conhecimento prudente para uma vida decente: um discurso sobre as ciências revisitado. São Paulo: Cortez. 2004.

MORIN, Edgar; MOIGNE, J.L. A inteligência da complexidade. São Paulo: Petrópolis, 2000.

MORIN, Edgar. Por uma reforma do pensamento. In: PENA-VEGA, Alfredo, NASCIMENTO, Elimar Pinheiro do. O Pensar Complexo. 2. ed. Rio de Janeiro: Garamond, 1999. p.21-34.

NICOLESCU, B. O Manifesto da Transdisciplinaridade. São Paulo: Editora Triom, 2001. 120p.

PAULA, João Antônio de. Crise e reiteração do capitalism dependente no Brasil. In: Capitalismo Globalizado e recursos territoriais. Rio de Janeiro: Lamparina, 2010.

RIBEIRO, Maria Teresa, F. Introdução. In: RIBEIRO, M.T.F. E MILANI, C.R.S (Org), Compreendendo a Complexidade socioespacial contemporânea: o território como categoria de diálogo interdisciplinar. Salvador: EDUFBA, 2009

RIST, Gilbert. Le développement: histoire d'une croyance occidentale. Paris: Presses de Science Po, 1996.

SACHS, I. Desenvolvimento e Cultura. Desenvolvimento da Cultura. Cultura do Desenvolvimento. In: Organização e Sociedade, Escola de Administração da Universidade Federal da Bahia. v. 12, n. 33, abr/jun. Salvador, 2005.

SAID, Edward W. Orientalismo: o oriente como invenção do ocidente. Trad. Rosaura Richenberg. São Paulo: Companhia da Letras, 2007. 523p

SEGURA, Denise de Sousa Baena. Educação ambiental na escola pública; da curiosodade ingênua à consciência crítica. São Paulo: AnnaBlume. 2001.

SANTOS, Milton. Relações espaço-temporais no Mundo Subdesenvolvido. In: Seleção de textos, 1 AGB - Seção Regional de São Paulo. Dez, 1976.

Entrevista. TD, p.32-39, fev./mar. 1999. Entrevista concedida a José Corrêa Leite 
. Da totalidade ao lugar. São Paulo: Edusp, 2005

Record, 2000.

Por uma outra globalização: do pensamento único à consciência universal. Rio de Janeiro:

SOUSA SANTOS, Boaventura. Para além do pensamento abissal; das linhas globais a uma ecologia de saberes. In: STARLING, H.M.M e ALMEIDA, S.R.G. (orgs). Sentimentos do Mundo; ciclo de conferências dos 80 anos da UFMG. Belo Horizonte: Editora da UFMG. 2009.

. Renovar a teoria crítica e reinventar a emancipação social. Tradução Muzar Benedito. São Paulo: Boitempo. 2007

Conhecimento prudente para uma vida decente: um discurso sobre as ciências revisitado. São Paulo: Editora Cortez, 2003.SANTOS, Boaventura S.. Um discurso sobre as ciências. Maria da Fé: Edições Afrontamento, 2001.

Um discurso sobre as ciências. Porto: Afrontamento. 1987

SMITH, Neil. O especto de Milton Santos. In: $O$ mundo do cidadão, um cidadão do mundo. São Paulo: SAVAIVA, Bauru: Associação dos Geográfos Brasileiros. 2000.

TUCKER, Vincent. The myth of development: a critique of Eurocentria. In: MUNCK, R.,

O'HEARN, D. Critical development theory: contributions to a new paradigm. London: Zed Books Ltd., 1999.

Notas

1 Unidade de Desenvolvimento Humano.

2 Localizada no bairro de Sete de Abril, em Salvador, Bahia.

${ }^{3}$ Pesquisa de campo do autor, feita no período de janeiro a maio de 2012.

Armando Castro é professor do Centro de Cultura, Linguagens e Tecnologias Aplicadas da Universidade Federal do Recôncavo da Bahia (CECULT / UFRB). Licenciado em Música pela UCSAL (1998), Especialista em História Social e Educação pela Universidade Católica do Salvador (2004), Mestre em Cultura \& Turismo pela Universidade Estadual de Santa Cruz/Universidade Federal da Bahia (2005) e Doutor em Administração pela UFBA (2011). Músico, compositor e produtor musical, integra o Grupo de Pesquisa O Som do Lugar e o Mundo (FFCH/UFBA). Organizou o livro digital Coisa de Artista: a inquietação pela autonomia (Edufba, 2014). É autor do livro sobre a Irmandade da Boa Morte, intitulado Irmãs de fé: tradição e turismo no Recôncavo Baiano (E-papers, 2006).

Maria Teresa Franco Ribeiro é Graduada em Economia pela UFMG (1977), Mestre em Desenvolvimento, Agricultura e Sociedade pela Universidade Federal Rural do Rio de Janeiro (1981) e Doutora em Economia da Industria e da Tecnologia pela UFRJ (1994). Professor Associado IV da UFBA. Atua na área de Economia, com ênfase em Economia do desenvolvimento e da Inovação, atuando principalmente nos seguintes temas: desenvolvimento territorial, competitividade, inovação, tecnologia, difusão, desenvolvimento sócio-ambiental. Membro do Instituto Voçoroca em Nazareno-Minas Gerais, com projetos voltados à recuperação e preservação do solo e da água. Realizou um Pós-doutorado no IHEAL (Université Paris III Sorbonne Nouvelle, 2006-2007), com o projeto: Desenvolvimento e interdisciplinaridade: explorando a interface entre a economia e a geografia. É membro fundador do LABMUNDO - Laboratório de Políticas Internacionais da EA/UFBA. 